\title{
Relevance of national and local government policy to sustainable community natural resource management in South Africa
}

\author{
C. Musvoto, K. Nortje, M. Murambadoro \& S. Dube \\ Council for Scientific and Industrial Research (CSIR), \\ Natural Resources and the Environment, South Africa
}

\begin{abstract}
Development in South Africa is guided by the principle of sustainability, and this is underpinned by integration, which is the consideration of social, economic and environmental factors in decision making. Policies are in place at national and local government level to ensure integration. A key integration instrument at municipality level (the lowest unit of local government) is the Integrated Development Plan (IDP), a strategic planning tool meant to guide all planning and management in a municipality. At national level, the National Environmental Management Act, in particular its philosophy of Integrated Environmental Management (IEM) is supposed to provide guidance on sustainable development. In municipalities, communal natural resource management decisions are made at community level. There are no instruments to guide this decision making to ensure integration. This study analysed natural resource management decision making at community level, focussing on agricultural land use. The objectives were (i) to assess whether agricultural land use decision making incorporated integration principles and (ii) to assess applicability of the IDP and IEM as instruments for incorporating integration into community level decision making. Information was collected through a review of national and local government policies and interviews at municipal and community levels. Decision making was found to be focused on addressing social and economic needs with little consideration for the environment. The IDP had no relevance to community level decision making while the principles of IEM could be applied to incorporate integration into decision making.

Keywords: agricultural land use, decision-making, integration, sustainable, natural resources; communal.
\end{abstract}




\section{Introduction}

South Africa has formally adopted the principle of sustainable development and this is reflected in the country's laws and policies, notably the National Environmental Management Act (NEMA) [1]. The NEMA Act defines sustainable development as 'the integration of social, economic and environmental factors in the planning, implementation and evaluation of decisions to ensure that development serves present and future generations'. Five priority areas of intervention required to achieve sustainable development have been identified [2] Two of these priority areas are 'enhancing systems for integrated planning and implementation' and 'sustaining ecosystems and using natural resources sustainably. Integration for sustainable resource utilisation is the focus of this paper. There are legal instruments at both national and local government level which are meant to ensure integration and sustainability of decisions and actions taken. At the local government level, Integrated Development Plans (IDPs) have this function, while at national level legislation such as NEMA has this role. Incorporated in NEMA is the philosophy of Integrated Environmental Management (IEM). IEM is 'a philosophy that is concerned with finding the right balance between development and the environment' whose vision, according to the Department of Environmental Affairs and Tourism [3], is to lay the foundation for environmentally sustainable development based on integrated and holistic environmental management practices and processes. IEM is presented as a philosophy that can be infused into decision making by all sectors of society (e.g. government/public sector, private sector and civil society) [4]. IEM is underpinned by a set of 11 principles.

Integrated Development Plans are a legislative requirement and are applied at municipality level. A municipality is the lowest division of local government in South Africa. Integrated Development Plans are standardised across all municipalities as they are required to cover a prescribed minimum set of issues. The IDP is a strategic five year planning instrument which guides and informs all planning, budgeting, management and decision making in a municipality. The plan considers economic and social development for a municipality and sets a framework for how land should be used, what infrastructure and services are needed and how the environment should be protected.

Within municipalities, in rural areas, communities are responsible for managing land and natural resources at local level. However, there are no guidelines for use at community level to ensure resource management is aligned with national and local government policies of integration and sustainable development. For sustainable development to be achieved, the principles of integration and sustainability have to be applied at all levels to all kinds of decisions including community level decisions. In the absence of guidelines for use at community level, could available instruments such as IDP and NEMA, specifically the NEMA principles of IEM principles be applied to guide community level natural resource management towards sustainable outcomes? This study assessed the applicability of the IDP, and the IEM principles of NEMA to natural resource management at community level in a rural 
agricultural municipality in South Africa, focusing on agricultural land use decision making.

The study was conducted in the Makhado Local Municipality in the Limpopo Province of South Africa. Makhado is a rural municipality in which agriculture is a key livelihood activity and a key component of the landscape. Agricultural landscapes in Makhado have to meet food and other livelihood needs of large numbers of people. Despite their crucial role in livelihoods, agricultural landscapes in Makhado are adversely affected by land degradation, in particular destruction of soil composition and structure, soil erosion and siltation of water bodies, with unsustainable agricultural practices being the main driver of these problems [5-7]. These environmental problems compromise the capacity of these landscapes to perform the different functions that are expected of them.

\section{Methods}

\subsection{The study site}

The study site was Tshakhuma area (Ward 29) in Makhado Municipality. In the South African context, a ward is a geopolitical subdivision of a municipality for purposes of administration and elections. It represents the lowest administrative unit in a municipality. Land at the study site is held under communal tenure and is under the control of traditional (tribal) leaders. In addition to traditional leaders, there are elected councillors in wards. Councillors are representatives of the local municipality at community level and representatives of the community at municipality level. The councillors work with traditional leaders.

Ward 29 land use is largely made up of rangelands and subsistence farming (Figure 1). Forest plantations and commercial agriculture comprise a small proportion of land use in the ward. From the land use, the ward is a source of a diversity of ecosystem goods and services such as food, water, wood, cultural services and carbon sequestration.

\subsection{Data collection}

Information on agricultural land use decision making was collected through a review of various documents and participative interaction with agricultural land use decision makers. Representatives of institutions directly involved in agricultural land use decision making, namely the Makhado Local Municipality and the traditional leaders in Tshakhuma (as representatives of the institution of the traditional leadership), were interviewed. In addition, the ward councillor for the area and farmers were interviewed. Semi-structured interviews which explored the theme of agricultural land use decision making focusing on role players, criteria for decision making and problems associated with agricultural land use decision making were used. The interviews were conducted in October 2010. Documents reviewed include the Makhado Municipality Integrated Development Plan [7] and its associated spatial plan (referred to as a Spatial Development Framework), the NEMA Act [1] and policy on IEM [4]. The 


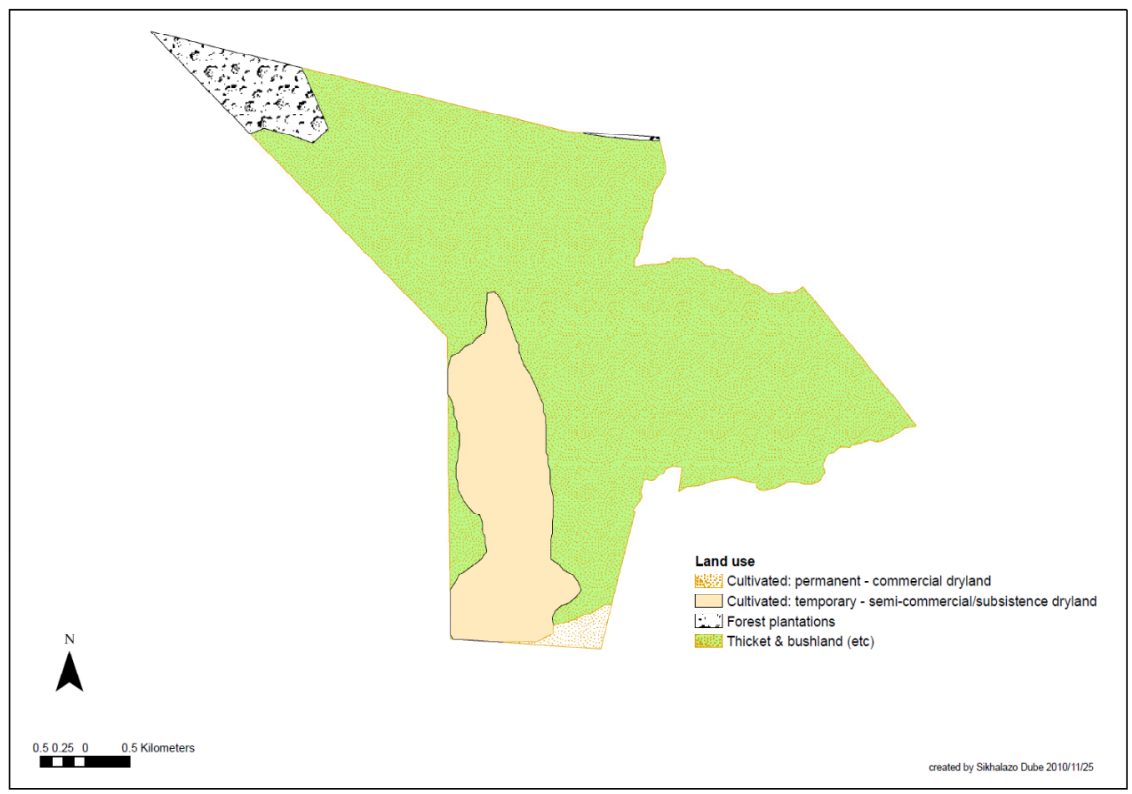

Figure 1: $\quad$ Land use in Ward 29 (Tshakhuma area) of Makhado Municipality.

Makhado IDP and IEM were analysed in the context of relevance to informing integrated community level agricultural land use decision making.

\section{Agricultural land use decision making}

\subsection{Level of decision making and role players}

Decisions that shape the agricultural landscape at community level are made at two levels: (i) the landscape level, where decisions pertain to the location of different agricultural land uses in the landscape and the allocation of land use rights to individuals (ii) the agroecosystem level where decisions relate to clearing of land, type of and management of agricultural activities. Landscape level decisions are made at the institutional level while the agroecosystem level decisions are made by individuals who have been given agricultural land use rights.

Landscape level agricultural land use decisions are made by traditional leaders, with the concurrence of ward councilors and the local municipality. Traditional leaders control and manage land in communal areas under their jurisdiction in terms of the Leadership and Governance Framework Act [8] and they also have control over other environmental resources. They allocate land for agriculture and other purposes to people in their communities. Additionally, traditional leaders are involved in shaping patterns of resource access that have material impacts upon rural households [9] through decisions on how the 
landscape is used and granting of permission to utilise communal resources such as wood. Ordinary community members do not have a say in allocation of land for agricultural purposes and the location of that land.

Once an individual had been allocated land through the appropriate traditional leadership, decisions about land use and management are then made by the individual land user. These decisions pertain to vegetation clearing, what crops to plant, when to plant them and how to plant them.

\subsection{Factors informing agricultural land use decision making}

Factors such as clan relationships, the need to minimize conflict between land holders, presence of features such as wetlands and rivers, and space limitations influence decisions taken by traditional leaders. Land allocation by traditional leaders is based on social relationships (clan relationships) and giving people opportunities. These relationships guide who is eligible to be allocated land and who is not. Minimizing conflict and maintenance of social cohesion through ensuring that there are no land disputes is a key consideration in allocating agricultural land. Before making a decision to allocate land, the traditional leaders check to ensure that land under consideration for allocation even if appearing to be vacant had not previously been allocated to someone else. The checks are done through consultation with relevant people on a case by case basis.

Presence of wetlands and proximity of land to rivers and water bodies influences land use decisions. Traditional leaders indicated that wetlands and land adjacent to rivers is not allocated for agricultural purposes. Decisions on allocation of agricultural land are also informed by the need to minimise conflict between different agricultural uses of land. Before land is allocated, the applicant had to disclose what they intend to use the land for. At the time of conducting the study land was only being allocated for cropping and not for livestock rearing as a way of minimizing tension and conflict between livestock and crop farmers in the limited space available for agriculture in Tshakhuma.

The factors which traditional leaders take into account in making agricultural land use decisions are not documented, formalised nor are they applied consistently. In discussing the intended outcomes and vision for agricultural land use decision making with traditional leaders, it emerged that other than the different criteria that are considered, there is no vision or clear outcome for agricultural land use which guides the decisions taken.

Factors such as culture, the need to generate income, external influences and availability of information influence decisions taken by individual land holders in terms of what to grow and how to grow it. Culturally, food crops such as maize and groundnuts have been planted but there is a general shift to fruit farming in the area. Some farmers continue to follow local cropping traditions and plant crops such as maize. The need to earn income has resulted in an increase in fruit tree planting and a decline in planting of crops such as maize. Fruit trees are considered to be cash crops whereas crops such as maize are planted for household consumption. 
External influences also affect decisions on what is planted. In Tshakhuma the increased planting of fruit trees for income generation is ascribed to the influence of surrounding commercial fruit farmers. The acquisition of knowledge and information on fruit farming also influences decisions on what to plant. Some people work on or had worked on fruit farms and acquired knowledge of fruit tree planting and management. A local university and the provincial department of agriculture provide information on different crops including fruit trees and this information influences decisions on choice of crops. The decisions taken by farmers are driven by the need to meet basic needs. In exploring the intended outcomes and vision for agricultural land use, it was acknowledged that there is no community level vision for agricultural land use.

\subsection{Synopsis of agricultural land use decision making in Tshakhuma}

Agricultural land use decisions in Tshakhuma are primarily biased towards meeting social and economic needs with environmental considerations receiving least attention (Table 1).

Table 1: Classification of factors which influenced agricultural land use decision making in Tshakhuma.

\begin{tabular}{|c|c|c|c|}
\hline \multirow{2}{*}{ Factor influencing decisions } & \multicolumn{3}{|c|}{ Classification } \\
\hline & social & economic & environmental \\
\hline Clan relationships & $\checkmark$ & & \\
\hline $\begin{array}{c}\text { Minimizing conflict between people and } \\
\text { avoiding land disputes }\end{array}$ & $\checkmark$ & $\checkmark$ & \\
\hline $\begin{array}{c}\text { Compatibility of different agricultural land } \\
\text { uses }\end{array}$ & $\checkmark$ & $\checkmark$ & \\
\hline $\begin{array}{c}\text { Land availability and size of land that is } \\
\text { available for allocation }\end{array}$ & $\checkmark$ & & \\
\hline Presence of wetlands & & & \\
\hline Proximity of land to river or water body & & & $\checkmark$ \\
\hline Culture & & & \\
\hline Need to generate income & & $\checkmark$ & \\
\hline Need to produce food & $\checkmark$ & $\checkmark$ & \\
\hline $\begin{array}{c}\text { External influences e.g. neighbouring } \\
\text { commercial farmers }\end{array}$ & $\checkmark$ & & \\
\hline Availability of knowledge and information & $\checkmark$ & & \\
\hline
\end{tabular}

The implications of decisions on the different ecosystem services that the environment provides are not considered. Decision making in Tshakhuma is ad hoc, as decisions made by both traditional leaders and individual farmers are meant to address specific needs but do not consider the broad outcome for agricultural land use nor the general implications of the decisions on the basis of social, economic and environmental considerations. 


\subsection{Problems related to agricultural land use in Tshakhuma.}

Decision makers in Tshakhuma acknowledged that there are problems linked to agricultural land use. Environmental problems and pressures linked to agricultural land use such as deforestation, erosion and siltation, degradation of ridges and mountains occur in Tshakhuma and other parts of the Limpopo Province. In addition to being mentioned in interviews in this study, these problems are also alluded to in various reports [5-7]. Minimizing these problems is not a factor in agricultural land use decision making in Tshakhuma. The Makhado Local Municipality (in interviews with municipal representatives and in the municipal Integrated Development Plan) [7] acknowledged that soil and vegetation resources were under severe stress, and this is ascribed to agricultural land use and factors such as high rural population densities and poorly planned settlements.

The interviews revealed that there are conflicts between different agricultural land uses in Tshakhuma, especially crop and livestock farming. These conflicts are caused by the increasing encroachment of cropping activities into grazing areas. The local municipality attributed this situation to poor decision making and planning at community level. Although the environmental problems documented in Tshakhuma are not all related to agricultural land use decision making, issues such as soil erosion caused by opening up of agricultural land on unsuitable land could be directly linked to landscape level decisions related to allocation of land for agriculture and to decisions taken by individual farmers on how to utilise the land allocated to them. Conflicts between crop and livestock farmers could also be directly linked to local level decision-making. The individual nature of agro-ecosystem level decision making in the absence of a common goal to which all ascribe to may be a key contributing factor to environmental problems.

\subsection{Improving integration in agricultural land use decision making}

The application of guidelines to ensure consideration of social, economic and environmental factors could improve integration in agricultural land use decision making.

\subsubsection{The Makhado Local Municipality Integrated Development Plan}

An analysis of the Makhado Municipality IDP for relevance to integrated community-level agricultural land use decision making shows that the IDP is pitched at municipal level and has little relevance to local level issues such as community use and management of resources such as agricultural land. Table 2 highlights the main characteristics of the IDP and their potential relevance to integrated community level decision making.

In Tshakhuma, community level decision makers are aware of the IDP and have, through public participation processes regularly participated in its development, but they do not use the IDP to guide agricultural land use or any other decisions on utilisation of natural resources. The reasons given for not 
Table 2: Characteristics of the Makhado Local Municipality integrated development plan and relevance to integrated community level agricultural land use decision making.

\begin{tabular}{|c|c|}
\hline $\begin{array}{c}\text { Characteristic of Integrated } \\
\text { Development Plan }\end{array}$ & $\begin{array}{c}\text { Applicability to integrated community } \\
\text { level routine agricultural land use } \\
\text { decision making }\end{array}$ \\
\hline $\begin{array}{l}\text { 1. Municipal strategic planning } \\
\text { instrument which guides all } \\
\text { planning, budgeting, management } \\
\text { and decision making. }\end{array}$ & $\begin{array}{l}\text { IDP addresses issues at a generic level } \\
\text { which is above local community issues. } \\
\text { IDP would be too broad and complex for } \\
\text { community level use. }\end{array}$ \\
\hline $\begin{array}{l}\text { 2. Long document (over } 100 \text { pages) } \\
\text { with maps. }\end{array}$ & $\begin{array}{l}\text { Length of document likely to discourage } \\
\text { routine use by community level decision } \\
\text { makers who only have to address issues at a } \\
\text { localised scale. }\end{array}$ \\
\hline $\begin{array}{l}\text { 3. Analyses situation in a municipality } \\
\text { (demographic features, settlements, } \\
\text { infrastructure, environmental } \\
\text { issues, economic issues). }\end{array}$ & $\begin{array}{l}\text { This information is general and not directly } \\
\text { applicable to community level agricultural } \\
\text { land use decision making. }\end{array}$ \\
\hline $\begin{array}{l}\text { 4. States vision and mission of } \\
\text { municipality. }\end{array}$ & $\begin{array}{l}\text { The municipal vision is abstract and does } \\
\text { not speak to a specific issue such as natural } \\
\text { resource management or agricultural land } \\
\text { use which a community can relate to. }\end{array}$ \\
\hline $\begin{array}{l}\text { 5. Lists strategic objectives or priority } \\
\text { issues for a municipality to address } \\
\text { e.g. housing, water, sanitation. }\end{array}$ & $\begin{array}{l}\text { Municipal strategic objectives not directly } \\
\text { relevant to community level agricultural } \\
\text { land use or natural resource objectives. }\end{array}$ \\
\hline $\begin{array}{l}\text { 6. Lists developmental objectives for } \\
\text { each priority issue e.g. addressing } \\
\text { housing backlog. }\end{array}$ & $\begin{array}{l}\text { Municipal developmental issues are above } \\
\text { community level natural resource issues. }\end{array}$ \\
\hline $\begin{array}{l}\text { 7. Lists development strategies for } \\
\text { identified priority issues e.g. } \\
\text { construction of water pipelines }\end{array}$ & $\begin{array}{l}\text { Municipal developmental strategies are } \\
\text { above routine community level natural } \\
\text { resource management issues. }\end{array}$ \\
\hline $\begin{array}{l}\text { 8. Lists projects, their location and } \\
\text { costs- projects are for identified } \\
\text { development strategies. }\end{array}$ & $\begin{array}{l}\text { Focus of IDP is not on routine issues which } \\
\text { are not project related, therefore provides } \\
\text { no guidance for dealing with routine issues } \\
\text { such as community agricultural land use } \\
\text { and its implications. }\end{array}$ \\
\hline
\end{tabular}

using the IDP include difficulty in understanding the IDP document; difficulty in reading and understanding the maps that are part of the IDP and the fact that the IDP is perceived as not speaking to community level issues.

From the analysis of the IDP and the opinions of community level decision makers, a combination of factors, including the presentation and focus make the 
Table 3: Relevance of the principles of Integrated Environmental Management to integrated community level agricultural land use decision making.

\begin{tabular}{|c|c|}
\hline IEM Principle & $\begin{array}{l}\text { Applicability to integrated community } \\
\text { level routine agricultural land use } \\
\text { decision making }\end{array}$ \\
\hline $\begin{array}{l}\text { 1. Clarification of accountability and } \\
\text { responsibility of all stakeholders. }\end{array}$ & $\begin{array}{l}\text { Directly applicable to community level } \\
\text { decision making to clarify roles and } \\
\text { responsibilities for all role players and } \\
\text { stakeholders. }\end{array}$ \\
\hline $\begin{array}{l}\text { 2. Adaptive - flexibility and } \\
\text { responding to realities. }\end{array}$ & $\begin{array}{l}\text { Applicable - decisions in Tshakhuma, for } \\
\text { example were driven by economic and } \\
\text { social realities and environmental realities } \\
\text { to a lesser extent. }\end{array}$ \\
\hline $\begin{array}{l}\text { 3. Identify and define all reasonable } \\
\text { alternatives - consider trade offs. }\end{array}$ & $\begin{array}{l}\text { Applicable to community level decision } \\
\text { making and would improve decision } \\
\text { making. Agricultural land use decision } \\
\text { making did not consider alternatives and } \\
\text { trade-offs. }\end{array}$ \\
\hline $\begin{array}{c}\text { 4. Promote community well-being } \\
\text { and empowerment- to participate } \\
\text { effectively in managing } \\
\text { environment. }\end{array}$ & $\begin{array}{c}\text { Applicable - speaks directly to } \\
\text { community involvement in addressing } \\
\text { environmental issues. }\end{array}$ \\
\hline $\begin{array}{l}\text { 5. Continual improvement of } \\
\text { environmental management in line } \\
\text { with vision and goal. }\end{array}$ & $\begin{array}{l}\text { Applicable: this principle would address } \\
\text { decision making shortcomings where } \\
\text { there was no goal or vision which guided } \\
\text { decision making. }\end{array}$ \\
\hline $\begin{array}{l}\text { 6. Dispute resolution: consensus- } \\
\text { seeking should guide processes and } \\
\text { should aim to avoid, minimise or } \\
\text { resolve conflicts wherever possible. }\end{array}$ & $\begin{array}{l}\text { Aligned to community level issues as } \\
\text { conflicts are a key consideration in } \\
\text { community level agricultural land use } \\
\text { decision making. }\end{array}$ \\
\hline $\begin{array}{l}\text { 7. Environmental justice - adverse } \\
\text { environmental impacts should not } \\
\text { be distributed so as to unfairly } \\
\text { discriminate against some people, } \\
\text { particularly vulnerable persons. }\end{array}$ & $\begin{array}{l}\text { Relevant as it would address } \\
\text { shortcomings in decision making where } \\
\text { environmental factors are not at the core } \\
\text { of decision making and there is a risk of } \\
\text { environmental impacts disproportionately } \\
\text { affecting some sectors of the community. }\end{array}$ \\
\hline $\begin{array}{l}\text { 8. Equity- equitable access to } \\
\text { environmental resources, benefits } \\
\text { and services - for present and } \\
\text { future generations. }\end{array}$ & $\begin{array}{l}\text { Directly applicable to community level } \\
\text { agricultural land use decision making as it } \\
\text { highlights factors which need to be } \\
\text { considered for integrated and sustainable } \\
\text { decision outcomes. }\end{array}$ \\
\hline
\end{tabular}


Table 3: $\quad$ Continued.

\begin{tabular}{|c|c|}
\hline IEM Principle & $\begin{array}{c}\text { Applicability to integrated community } \\
\text { level routine agricultural land use } \\
\text { decision making }\end{array}$ \\
\hline $\begin{array}{c}\text { 9. Holistic decision-making: decisions } \\
\text { should consider the interests, needs } \\
\text { and values of all interested and } \\
\text { affected parties and utilise all } \\
\text { relevant forms of knowledge. }\end{array}$ & $\begin{array}{c}\text { Relevant as it would consider needs of all } \\
\text { stakeholders and directly address } \\
\text { shortcomings where decision making } \\
\text { focused on meeting social and economic } \\
\text { needs. }\end{array}$ \\
\hline $\begin{array}{c}\text { 10. Informed decision-making: use of } \\
\text { sound and relevant information } \\
\text { based on application of the most } \\
\text { suitable methods and techniques to } \\
\text { rigorously address the issues that } \\
\text { really matter. }\end{array}$ & $\begin{array}{c}\text { Relevant as it would help ensure that } \\
\text { decisions consider all relevant information } \\
\text { and factors. }\end{array}$ \\
\hline $\begin{array}{c}\text { 11. Integrated approach: recognition } \\
\text { that all elements of the } \\
\text { environment are linked and } \\
\text { interrelated, and consideration of } \\
\text { effects of decisions on all } \\
\text { components of the environment } \\
\text { and all stakeholders. }\end{array}$ & $\begin{array}{c}\text { Applicable at community level as it } \\
\text { addresses interrelationships and linkages. } \\
\text { Relevant to addressing decision making } \\
\text { shortcomings where interrelationships and } \\
\text { linkages are not considered. }\end{array}$ \\
\hline
\end{tabular}

IDP irrelevant for application to local level decision making as a tool for guiding decision making towards integration.

\subsubsection{Integrated Environmental Management}

Integrated Environmental Management is a national level instrument which provides generic integration guidelines that would be applicable in different contexts. Such high level guidelines would be unlikely to be directly relevant to local level issues such as community level natural resource management decision making and would likely require adaptation for application at local level. An analysis of the relevance of the eleven principles of IEM to agricultural land use decision making at community level is presented in Table 3.

Decision makers in Tshakhuma are not aware of IEM and its principles. Although IEM is a national level instrument, its principles were found to be more directly applicable to community level agricultural land use and other natural resource management decision making than the municipal IDP. The IEM principles provide a systematic way of considering factors and could be used to structure decision making so that it addresses the needs of the community in a way that integrates social, economic and environmental factors.

Agricultural land use decision making in Tshakhuma is dominated by social and economic considerations. Integration could be improved if the decision 
making process incorporated the provisions of the IEM principles, particularly those which address environmental factors (principles 5, 7, 8 and 11). Despite some of the shortcomings in decision making, there is clear accountability and responsibility in the way decisions are made, and this makes it possible to target interventions for improvement of integration at the decision makers. The priority target group for applying the IEM principles would, be traditional leaders as they are at the 'coalface' of landscape level decision making, and are also in a position to influence agroecosystem level decisions through their interaction with individual landholders.

\section{Conclusion}

The priority for community level agricultural land use decision makers in Tshakhuma is responding to immediate social and economic needs with little consideration for the environment and the different ecosystem services it provides. This approach is linked to environmental degradation, and if not addressed, this could undermine the environment so that in future it would not be possible to meet social and economic needs. More integrative decision making approaches, centred on nurturing sustainable agricultural land use are required to ensure that decisions taken do not undermine the very realities which decision makers seek to address. Such decision making approaches would need to be underpinned by an explicit vision for agricultural land use. Integrated Development Plans, although meant to guide decision making at municipal level do not speak to community level issues while IEM, a national level instrument is more relevant to community level decision making. If all the IEM principles are applied systematically, all the factors relevant to integrated decision making at community level would be addressed. The principles of IEM would have to be presented in a way that is easily understood by decision makers.

\section{References}

[1] Republic of South Africa, 1998. The National Environmental Management Act (Act No 107 of 1998). Government Printer, Pretoria.

[2] DEAT (Department of Environmental Affairs and Tourism), People-planetprosperity: A National Framework for Sustainable Development in South Africa, 2008.

[3] DEAT, A National Strategy for Integrated Environmental Management in South Africa, Discussion Document, Department of Environmental Affairs and Tourism, Pretoria, 1998.

[4] DEAT, Overview of Integrated Environmental Management, Integrated Environmental Management, Information Series 0, Department of Environmental Affairs and Tourism (DEAT), Pretoria, 2004. http://www.environment.gov.za/Services/documents/Publications/seri es_0.pdf

[5] Limpopo overview state of the environment, 2003. http://www.environment.gov.za/soer/reports/limpopo/Limpopo.pdf 
[6] Limpopo Department of Finance and Economic Development, Limpopo State of the Environment Report (Phase 1), 2004 http://soer.deat.gov.za /dm_documents/Limpopo_State_of_environment_reporting phase_1_Ur ZKg.pdf

[7] Makhado Local Municipality, Integrated Development Plan 2010/11 IDP Review, pp. 43-44. 2010.

[8] Republic of South Africa, 2003. Traditional Leadership and governance Framework Act (Act No 41 of 2003). Government Printer, Pretoria.

[9] King, B.H., 2004. Spaces of change: Tribal authorities in the former KaNgwane homeland, South Africa, 2004.http://www.uneca.org/itca /governance/Documents/Tribal\%20Authorities\%20in\%20Kangwane\%20S A.pdf 